\title{
THE INFLUENCE OF GOVERNMENT ROLE, COMMUNITY PARTICIPATION AND SOCIAL CAPITAL ON THE QUALITY OF DESTINATION AND COMMUNITY WELFARE IN THE TOURISM VILLAGE OF BADUNG REGENCY PROVINCE OF BALI
}

\author{
Agustina Made Dian Putri, Budhi Made Kembar Sri, Utama Made Suyana, \\ Yasa I G.W. Murjana \\ Faculty of Economics and Business, University of Udayana, Bali, Indonesia \\ *E-mail: dianagustina03@yahoo.com
}

\begin{abstract}
The purpose of this study is to analyze: (1) the influence of the government's role on community participation; (2) the influence of the role of government, community participation and social capital on destination quality; (3) the influence of the role of government, community participation, social capital and destination quality on community welfare; (4) the role of community participation in mediating the influence of the government's role on the quality of destinations; (5) the role of community participation in mediating the influence of the government's role on community welfare; (6) the role of destination quality in mediating the influence of the role of government, community participation and social capital on community welfare; and (7) the role of community participation and destination quality in mediating the influence of the government's role on community welfare. The results of the research and data analysis show that: (1) the role of the government directly has a positive and significant effect on community participation; (2) the role of government, community participation and social capital directly have a positive and significant effect on the quality of destinations; (3) the role of government, community participation, social capital and destination quality directly have a positive and significant impact on community welfare; (4) community participation is a mediating variable that is capable of partially mediating the influence of the government's role on the quality of destinations; (5) community participation is a mediating variable that is capable of partially mediating the influence of the government's role on community welfare; (6) destination quality is a mediating variable that is able to play a part in mediating partially the influence of the role of government, community participation and social capital on community welfare; and (7) community participation and destination quality is a mediating variable that is able to play a part in mediating partially the influence of the government's role on community welfare.
\end{abstract}

\section{KEY WORDS}

Government roles, community participation, social capital, destination quality, community welfare.

Development so far has focused more on the development of the secondary sector aimed at improving the community's economy; in fact it has not fully provided welfare for the community equally, especially rural communities. This is because community empowerment in planning, implementing and enjoying the results of development in various sectors is still relatively lacking. This phenomenon is reinforced by the statement of Pranoto et al. (2006), which states that development policies for the region so far have not made significant changes to the improvement of the welfare of the community, and have even caused gaps between urban and rural areas.

The tourism sector is considered as a means to achieve sustainable development by providing very significant benefits in the economic, environmental and socio-cultural fields as well as the broadest opportunities for local people to improve their welfare (Sharpley, 2002). Efforts to find the link between tourism and sustainable development were stated by Sharpley (2009) which states that sustainable tourism development is a development that is focused on two things, on the one hand sustainability as an economic activity, and the other is a policy oriented towards long-term goals and between generations. The development of 
the region into a tourism destination naturally causes changes in all aspects of people's lives, one of which is the change in livelihoods. These changes generally occur because of the desire of the people in tourism destinations to change their economic conditions, whether they are individuals, families, business groups or community groups (Prasiasa, 2010).

Province of Bali as one of the well-known tourist destinations both domestically and abroad in developing its tourism sector does not deviate from the national tourism development mission. The Provincial Government of Bali is working on making the people in the villages benefit from tourism through the rural tourism development program in the district by utilizing cultural, natural capital and attractions that are of interest. The problem that occurs in the tourism village of Badung Regency is that the potential utilization is not yet optimal through the lack of tourism products and attractions to tourists. This is inseparable from institutional management and community participation that not all tourist villages have good patterns. The quality of tourism destinations must be continuously improved as a result of tourists who are increasingly smart and demanding to be able to get more (more demanding) and can get value for money and is also caused by increasingly competitive competition of local, regional and international destinations. Local community participation in tourism development can be seen from two perspectives, namely participation in the decision making process (decesion making process) and participation related to the benefits received by the community (perceived benefit) from the existence of tourism development in the region (Timothy, 1999). The success of tourism development can be seen from the participation of local communities in decision making at various stages, namely the problem identification stage, planning, implementation, monitoring and evaluation (Zhao \& Ritchie, 2007). One of the social capitals needed to support the success and sustainability of a natural tourism development is the existence of a social network that occurs between visible stakeholders (Lyon in Rachmawati, et al, 2011). The things that can influence the formation of social networks are the good relations between the stakeholders involved (Weiler and Laing in Rachmawati, et al, 2011).

Improving the quality of destinations in the tourism village of Badung Regency is inseparable from the role of the government, community participation and social capital in the community. The role of the government as regulator, motivator, facilitator and dynamist is needed in the development of tourism in a region. The government can develop policies, facilitate, motivate and collaborate with stakeholders to improve the quality of the destination.

\section{THEORETICAL BACKGROUND}

Taroepratjeka (1998), said that tourism activities are activities that bring people together with a situation outside their environment and can cause awe, feel comfort and can even cause challenges to themselves. The situation in question can manifest as a state of nature, culture and special conditions, both as an object and attraction.

Sustainable development (Salim, 1990) aims to improve the welfare of society, to meet human needs and aspirations. Sustainable development is basically intended to seek equitable distribution of development between generations in the present and the future.

Pezzey (1992), sees aspects of sustainability from different sides. He sees that sustainability has a static and dynamic meaning. Sustainability from the static side is defined as the utilization of renewable natural resources at a constant technological pace, while sustainability from the dynamic side is defined as the utilization of non-renewable natural resources at a constantly changing level of technology.

Because of this multidimensional and multi-interpretation, experts agree to temporarily adopt the understanding agreed upon by the Brundtland commission which states that "Sustainable development is development that meets the needs of the current generation without reducing the ability of future generations to meet their needs." There are two things that implicitly concern in the Bruntland concept. First, it concerns the importance of paying attention to natural resource and environmental constraints on development and consumption patterns. Second, concerns attention to the well-being of future generations. Hall (1998) states that the assumption of sustainability lies at least in three basic axioms; 1) 
Current and future treatments that place positive values in the long run; 2) Recognizing that environmental assets contribute to economic wellbeing; 3) Knowing the constraints due to implications that arise on environmental assets.

Dengnoy in Nugroho and Aliyah (2013) stated that the development of communitybased tourism was developed based on the principle of balance and harmony between the interests of various stakeholders in tourism development including the government, private sector and the community. Community-based tourism development aims to: 1) empower the community; 2) increasing the role and participation of the community in tourism development in order to obtain economic, socio-cultural benefits from tourism development; 3) provide equal opportunities to all members of the community. Therefore community-based tourism development requires coordination and cooperation as well as a balanced role between various stakeholders including the government, the private sector and the community.

Community-based tourism must pay attention to the involvement of local communities which is an absolute requirement for achieving sustainable tourism development. The management must be carried out by local people whose lives and lives are affected by the development (Pitana, 2002), so that it will lead to a community-based management system as the main actor in tourism.

The approach that can be used to develop community-based tourism is a participatory approach. This approach is used to encourage the formation of partnerships between the relevant parties (stakeholders). In this case the local community must be made aware of the potential they have so that they have a sense of belonging (sense of belonging) to a variety of natural and cultural resources as assets of tourism development. Furthermore, if tourism stakeholders are associated with community-based tourism (Natori, 2001), then tourists are the capital that will be processed by the three components of stakeholders (government, tourism entrepreneurs, and the community) whose results will be enjoyed by tourists.

A tourism destination is an area specifically designated and promoted as a tourist destination, in which all tourism products are coordinated by one particular organization (European Communities, 2003). According to Richardson and Fluker (2004), tourism destinations are defined as "A significant place visited on a trip, with some form of actual or perceived boundary. The basic geographic unit for the production of tourism statistics".

Mill \& Morrison (2012) use another term about this destination, namely Destination Mix, which is a group of elements that have a dependency on one another to create a tourist experience for tourists. Destination mix consists of: 1). Attraction, 2). Facilities, 3). Infrastructure, 4). Transportation, and 5). Hospitality Meanwhile, Morrison (2013) states in more detail that the destination mix consists of accommodation, restaurants, tourist attractions, events, transportation, infrastructure and hospitality. The opinion of Mill \& Morrison (2012) and Morrison (2013) can be concluded that the products that must be provided by the destination for visitors consist of tourist attractions (including events), accommodation, transportation, infrastructure and hospitality.

Markandya et al. (2003) stated that one of the main roles of the government in the field of tourism is to make policies and legislative frameworks. Meanwhile Cameron, A. M, et al (2001) stated that local government (regency / city) has two main functions related to tourism namely: 'empowerment' of tourism development, and management of tourism impacts.

Local governments through the rules they have made have a great influence on the success of the local tourism industry, and play a role in preserving the assets in the destination. With these rules, tourism destinations will be maintained and remain attractive to most visitors, which is characterized by three main factors, namely: a positive image of the destination and travel experience, safety and comfort, and overall environmental quality (Clark, B. 2006).

Local community participation in tourism development in general can be seen from at least two dimensions, namely community participation in the decision making process and in receiving benefits. At the level of decision making, people are encouraged to have control over tourism resources, have initiative and be able to make decisions that can influence and improve their quality of life (Timothy, 1999; Tosun, 1999; Zhao \& Ritchie, 2007). 
The participation of local people at the level of benefit acceptance can be reflected in the increase in income, employment, and education of local people about tourism and entrepreneurship, as well as increased public awareness of tourism. Increased public awareness will create a friendlier environment for tourists and be able to improve the image of the destination, which in turn will increase the capacity of the community to receive benefits from tourism activities (Timothy, 1999).

Coleman (1998) defines that social capital is an aspect of social structure that makes it easy for the actions of individuals or actors in a social structure. Cohen and Prusak (2001), define that social capital is a stock of the active relationships of a society. Each pattern of relationship is bound by trust, mutual understanding, and shared values, which bind group members to make possible joint actions carried out efficiently and effectively.

To support this statement, Hasbullah (2006) again recommends that social capital as everything related to cooperative behavior with the community to achieve a better quality of life, which in its implementation is supported by the values and norms that become its main element, as; mutual trust (trust), reciprocity and collective rules in a society.

Friedlander (1980) said that welfare is an organized system that is carried out through social services and institutions with the aim of helping individuals and groups achieve a satisfying level of life and health and personal and social relationships that provide opportunities for them to develop all of their abilities and to improve their welfare in accordance with the needs of the family and community.

According to Lokshin and Ravallion (2000), welfare can be seen from two approaches namely objective well-being and subjective well-being. Subjective well-being can describe various aspects of life, including employment, economic activity, level of independence, life span, and leisure. Milligan, et al (2006) explain that objective well-being is the level of welfare of individuals or groups of people measured on average by certain benchmarks, both economic, social and other measures. Meanwhile, Suandi (2006) states that the welfare of an individual is seen personally as measured in the form of satisfaction and happiness.

\section{METHODS OF RESEARCH}

This study uses a quantitative data approach with a Likert scale measurement which is then processed using the least square partial data processing technique (PLS). The thought process framework, research conceptual framework, research model and hypothesis are built with guidelines on the theories and results of previous studies that are relevant to this study. The research framework and research hypotheses are as follows.

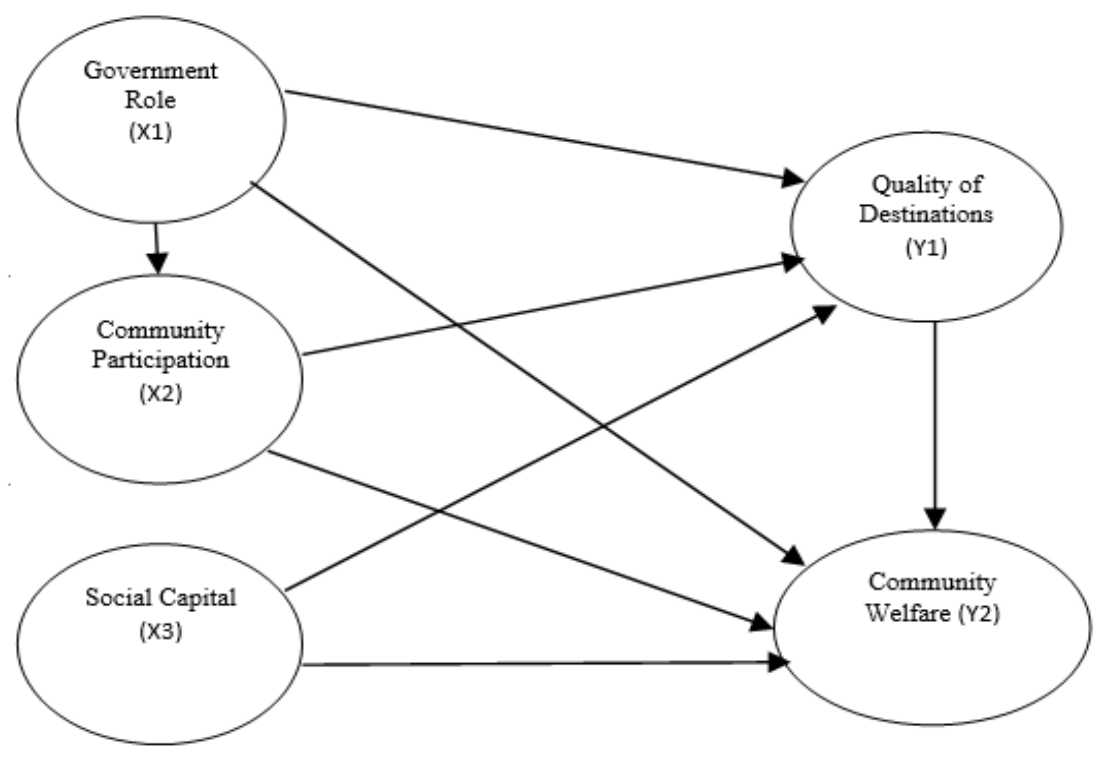

Figure 1 - Research Framework 
Based on Figure 1, the hypothesis formulation can be elaborated as follows:

1) The role of government has a positive and significant effect on community participation in the Tourism Village of Badung Regency, Bali Province;

2) The role of government has a positive and significant effect on the quality of destinations in the Tourism Village of Badung Regency, Bali Province;

3) Community participation has a positive and significant effect on the quality of destinations in the Tourism Village of Badung Regency, Bali Province;

4) Social capital has a positive and significant effect on the quality of destinations in the Tourism Village of Badung Regency, Bali Province;

5) The role of government has a positive and significant effect on the welfare of the community in the Tourism Village of Badung Regency, Bali Province;

6) Community participation has a positive and significant effect on community welfare in the Tourism Village of Badung Regency, Bali Province;

7) Social capital has a positive and significant effect on community welfare in the Tourism Village of Badung Regency, Bali Province;

8) Destination quality has a positive and significant impact on community welfare in the Tourism Village of Badung Regency, Bali Province;

9) Community participation significantly mediates the effect of the government's role on destination quality in the Tourism Village of Badung Regency, Bali Province;

10) Community participation significantly mediates the effect of the government's role on community welfare in the Tourism Village of Badung Regency, Bali Province;

11) Destination quality mediates significantly the influence of the government's role on community welfare in the Tourism Village of Badung Regency, Bali Province;

12) Destination quality mediates significantly the effect of community participation on community welfare in the Tourism Village of Badung Regency, Bali Province;

13) Destination quality mediates the positive and significant influence of social capital on community welfare in the Tourism Village of Badung Regency, Bali Province;

14) Community participation and destination quality mediate the positive and significant influence of the government's role on community welfare in the Tourism Village of Badung Regency, Bali Province.

This research takes place in the Tourism Village of Badung Regency which consists of 11 tourism villages located in Central Badung and North Badung Regencies which are then selected purposively in three tourist villages namely Sangeh Tourism Village, Pangsan Tourism Village and Belok Sidan Tourism Village on the basis of consideration of the facts the development of tourism villages in Badung Regency has not shown maximum results (Suryasih, et al, 2014; Nalayani, 2015; Anom, et al, 2015).

This research uses two types of data, primary data and secondary data. The data source of this research is quantitative data that is data on the number of tourist visits, data on the number of accommodation companies / businesses, and other data owned by Badung Regency and Badung Regency tourism village. The qualitative data used is data in the form of community responses to the quality of the destination, the role of the government, participation and social capital owned by the community in the tourism village of Badung Regency and data in the form of a picture of a tourism village in Badung Regency.

The population in this study are the people who are directly involved with tourism activities, namely the people who have direct links both economically and socially culturally with tourism activities. This population category includes, among others, people who open businesses related to tourism (restaurants, lodging, stalls around attractions, etc.), artists, handicraft makers, members of tourism association groups such as Pokdarwis, STA (Sangeh Tourism Activity) which amounted to 285 people then by using the Slovin formula obtained a sample size of 166 .

Data collection methods in this study are the method of observation and interview methods. Non-behavioral observation method to collect secondary data from related agencies such as tourist visit data, number of companies / accommodation businesses in Badung Regency, tourism villages in Badung Regency. In-depth interviews (in-depth interview), which are used to obtain primary data from community leaders as informants in 
the relevant and competent research areas provide information in accordance with the objectives of this study including the customary village apparatus and tourism object managers in Sangeh Tourism Village, Pangsan Tourism Village and Belok Sidan Tourism Village.

The role of government is defined as direct and indirect government involvement in development activities in an area that can influence the success of the development. Government role variables are reflected by indicators of the government's role as motivators, facilitators and dynamists (Pitana and Gayatri, 2005).

Community participation in this study is defined as community participation individually, in groups or in community unity in a process of developing tourist villages. The community participation variable is reflected by indicators, namely involvement in the planning stage, involvement in the development implementation stage, involvement in the management stage, and involvement in the monitoring and evaluation phase (Priasukmana and Mulyadin, 2001).

Social Capital in this research is interpreted as a source that arises from the interaction between people in a community. The social capital variable is reflected by indicators of trust, networks and norms (Fukuyama, 1995 and Putnam, 1993).

Destination Quality is the quality of an area that is specifically designated and promoted as a place of visit for tourists and in which all tourism products are coordinated by a particular organization. Destination quality in this study was measured by four refective indicators, namely attraction, amenities, accessibility and institutional (ancillary service) (Cooper, et al., 1993).

Community welfare is the welfare of the people involved in tourism activities in the tourism village of Badung Regency, which can be seen from the indicators namely income, fulfillment of basic needs, fulfillment of educational needs and health conditions (BPS, 1991).

In this study data analysis using Partial Least Square (PLS) approach. In PLS, not all the weights of each indicator are assumed to be the same for latent variables, but these indicators have various weights, so indicators with lower weights will also contribute lower to the score of latent variables (Chin et al., 1996).

The results of the PLS data processing are then carried out in two stages of evaluation, namely the evaluation of the outer model and the inner model. The first step is evaluating the measurement model or outer model which is carried out in accordance with the relationship between the indicator and its construct. Evaluation of measurements is carried out by: 1) Convergent Validity with a tolerance value of at least 0.50 ; 2) Reliability and Validity constructs with internal consistency and crinbach alpha values must be greater than 0.70 and the maximum AVE value is 0.50 ; and 3 ) Discriminant Validity. The second stage is done by looking at the validity of the inner model which is done with three types of evaluations, namely 1 ) evaluation of goodness of fit; 2) test for direct influence and 3) test for indirect effect or mediation.

\section{RESULTS AND DISCUSSION}

Based on the test of validity and reliability that has been done, states every question and variable has been valid and reliable.

The result of PLS output regarding convergent validity is known that all indicators that form the construct in this study are statistically significant with a t value greater than 1.96 with a p.value of $\leq 0.05$. Likewise, all loading values are above 0.50 , discriminant validity has also been fulfilled.

Based on Table 1 it can be seen that the constructs of Government Role (X1), Community Participation (X2), Social Capital (X3), Destination Quality (Y1), and Community Welfare (Y2) are very good, because they have discrimant validity that is far greater than 0,5 which is reflected in the Average Variance Extracted Value (AVE), and above 0.70 for Composite Reliability and Cronbach Alpha which exceeds 0.60. 


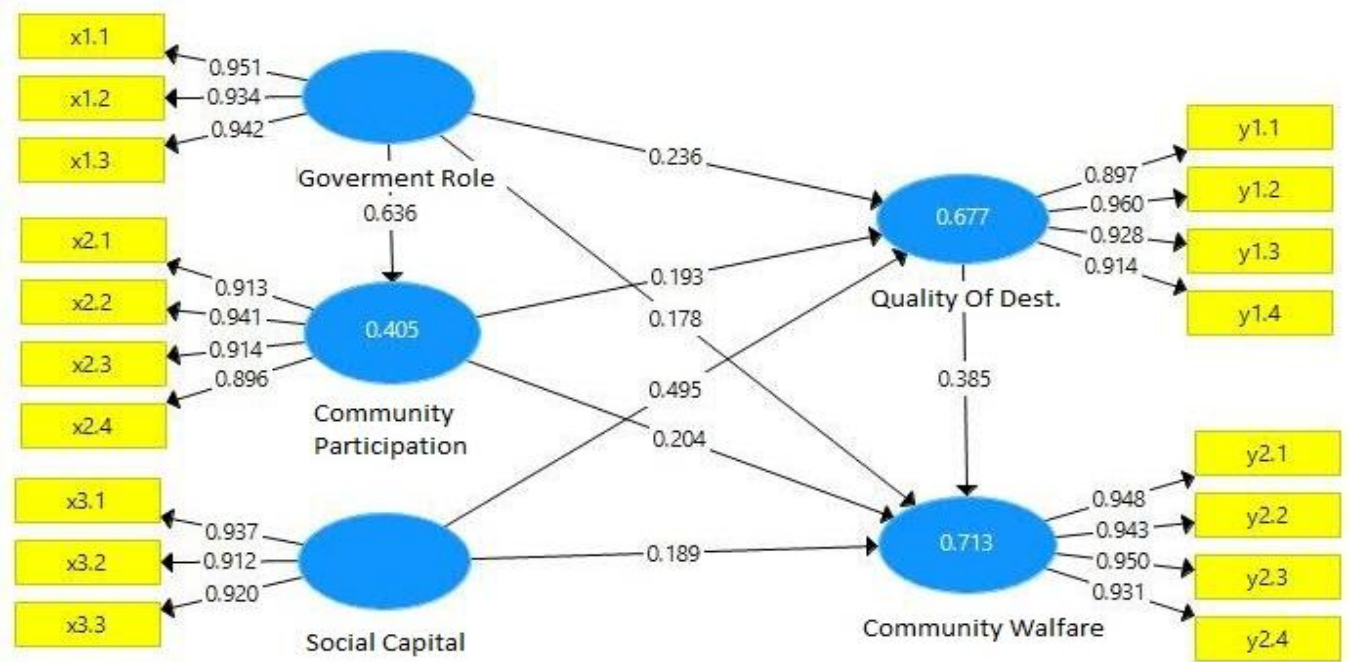

Figure 2 - Results of the Influence of Government Role, Community Participation and Social Capital on the Quality of Destinations and Community Welfare

Table 1 - Average Variance Extracted (AVE), Composite Reliability (CR), and Cronbach Alpha on each research variable

\begin{tabular}{cccc}
\hline Variable & Average Variance Extracted (AVE) & Composite Reliability & Cronbach's Alpha \\
\hline Role of Government (X1) & 0,888 & 0.970 & 0,937 \\
Community Participation (X2) & 0,839 & 0,960 & 0,936 \\
Social Capital (X3) & 0,852 & 0,945 & 0,913 \\
Destination Quality (Y1) & 0,856 & 0,954 & 0,944 \\
Welfare (Y2) & 0,890 & 0,960 & 0,959 \\
\hline
\end{tabular}

Source: Processed from Raw Data, 2019.

Table 2 - R-square

\begin{tabular}{lll}
\hline Variable & R Square & Explanation \\
\hline Community Participation & 0,405 & Moderate \\
Destination Quality & 0,677 & Strong \\
Welfare & 0,713 & Strong \\
\hline
\end{tabular}

Source: Processed from Raw Data, 2019.

The results of the analysis of the $\mathrm{R} 2$ values obtained from the calculation results show a wide distribution. In Table 3 , it can be seen that two of the sub-measurement variables have good determinant coefficient values, namely destination quality and community welfare variables. Only the community participation variable has good criteria.

$$
\begin{aligned}
& Q^{2}=1-\left[\left(1-R_{1}{ }^{2}\right)\left(1-R_{2}{ }^{2}\right) \ldots . .\left(1-R_{p}{ }^{2}\right)\right] \\
& Q^{2}=1-\left[\left(1-R_{1}^{2}\right)\left(1-R_{2}^{2}\right)\left(1-R_{3}^{2}\right)\right] \\
& Q^{2}=1-[(1-0,405)(1-0,677)(1-0,713)] \\
& Q^{2}=1-[(0,595)(0,323)(0,287)] \\
& Q^{2}=1-0,055=0,945
\end{aligned}
$$

Based on the calculation results obtained a Q2 value of 0.945 can be interpreted that 94.50 percent of the variation of the community welfare variable (Y2) is expressed by variations in the government role variable (X1), community participation (X2), Social Capital (X3), and Destination Quality (Y1), while the remaining 9.30 percent of the variation in value changes in the community welfare variable cannot be explained by exogenous latent variables $\left(X_{1}, X_{2}, X_{3}\right.$, and $\left.Y_{1}\right)$, and is determined by other factors not included in this research model.

Table 3 shows that the role of government has a positive and significant effect on community participation as evidenced by the $P$ Value where the value is less than 0.05 so 
that it is declared significant. The role of government, community participation and social capital has a positive and significant impact on the quality of destinations. Furthermore, the roles of government variables, community participation and social capital have a positive and significant effect on people's welfare.

Table 3 - Path Coefficients (Direct Effects)

\begin{tabular}{|c|c|c|c|c|c|}
\hline Variable & $\begin{array}{l}\text { Original } \\
\text { Sample }\end{array}$ & $\begin{array}{l}\text { Standard } \\
\text { Deviation }\end{array}$ & $\begin{array}{c}\mathrm{T} \\
\text { Statistics }\end{array}$ & $\begin{array}{c}\mathrm{P} \\
\text { Values }\end{array}$ & \\
\hline Govt. Role $\rightarrow$ Community Participation & 0,636 & 0,058 & 10,955 & 0,000 & Significant \\
\hline Govt. Role $\rightarrow$ Destination Quality & 0,236 & 0,098 & 2,394 & 0,041 & Significant \\
\hline Govt. Role $\rightarrow$ Welfare & 0,178 & 0,079 & 2,247 & 0,000 & Significant \\
\hline Community Participation $\rightarrow$ Destination Quality & 0,193 & 0,084 & 2,284 & 0,017 & Significant \\
\hline Community Participation $\rightarrow$ Welfare & 0,204 & 0,085 & 2,400 & 0,023 & Significant \\
\hline Social Capital $\rightarrow$ Destination Quality & 0,495 & 0,112 & 4,414 & 0,025 & Significant \\
\hline Social Capital $\rightarrow$ Welfare & 0,189 & 0,092 & 2,050 & 0,017 & Significant \\
\hline Destination quality $\rightarrow$ Welfare & 0,385 & 0,083 & 4,636 & 0,000 & Significant \\
\hline
\end{tabular}

Source: Processed Raw Data, 2019.

Table 5 - Indirect Effects

\begin{tabular}{|c|c|c|c|c|c|c|}
\hline Variable & Mediating Variables & $\begin{array}{l}\text { Original } \\
\text { Sample }\end{array}$ & $\begin{array}{l}\text { Standard } \\
\text { Deviation }\end{array}$ & $\begin{array}{c}\mathrm{T} \\
\text { Statistics }\end{array}$ & $\begin{array}{c}\mathrm{P} \\
\text { Values }\end{array}$ & \\
\hline Govt. Role $\rightarrow$ Destination Quality & $\begin{array}{l}\text { Community } \\
\text { Participation }\end{array}$ & 0,123 & 0,054 & 2,260 & 0,024 & Sig. \\
\hline Govt. Role $\rightarrow$ Welfare & $\begin{array}{l}\text { Community } \\
\text { Participation }\end{array}$ & 0,130 & 0,056 & 2,310 & 0,021 & Sig. \\
\hline Govt. Role $\rightarrow$ Welfare & $\begin{array}{l}\text { Destination Quality } \\
\text { Community }\end{array}$ & 0,091 & 0,041 & 2,223 & 0,027 & Sig. \\
\hline Govt. Role $\rightarrow$ Welfare & $\begin{array}{l}\text { Participation and } \\
\text { Destination Quality }\end{array}$ & 0,047 & 0,024 & 1,991 & 0,047 & Sig. \\
\hline Community Participation $\rightarrow$ Welfare & Destination Quality & 0,074 & 0,037 & 1,985 & 0,048 & Sig. \\
\hline Social Capital $\rightarrow$ Welfare & Destination Quality & 0,190 & 0,062 & 3,063 & 0,002 & Sig. \\
\hline
\end{tabular}

Source: Processed from Raw Data, 2019ю

Based on Table 5 it is known that all mediation relationships in this test are positive and significant $(P$ values $<0.05)$. By looking at the direct effects of the research variables in Table 4 and the indirect effects in Table 5, it can be stated that the direct influence of the role of government on the quality of the destination has a significant effect and after passing through other variables or mediated by community participation the effect is significant. This shows that the role of community participation mediation is "partial" mediation. The direct influence of the role of government on community welfare is significant and after going through other variables or mediated by community participation it has a significant effect. Similarly, through two mediating variables namely community participation and destination quality also have a significant effect. This shows the role of community participation mediation is "partial" mediation and also the role of community participation mediation and destination quality is "partial" mediation. The direct influence of the role of government, community participation and social capital on community welfare has a significant effect, and after passing through other variables or being mediated by destination quality variables it becomes significant, this shows the mediating role of the "partial" destination mediation variable quality.

\section{DISCUSSION OF RESULTS}

Testing the hypothesis in this study proves that the role of government has a positive and significant influence on community participation. The results of this study reflect that the role of government influences community participation in the Tourism Village of Badung Regency, Bali Province. This is in line with the study of community-based tourism theory and empirical studies of the relationship between the role of government and community participation.

The role of the Badung Regency Government in encouraging community participation in tourism villages is carried out by motivating the community about the importance of 
managing tourism villages. The role of the Badung Regency Government in the participation of the community in the tourism village, must answer the needs of the community and tourists, as expected by the community. As the implication of community-based tourism development, the role of the government in increasing community participation has clearly been demonstrated by the growing social, economic, cultural and political dimensions in society. The social dimension appears in the form of community involvement to jointly maintain tourism activities in tourist villages, by realizing Sapta Pesona. The economic dimension is in the form of development, various groups of craftsmen, souvenirs, culinary, lodging, stalls, etc., which are able to meet the needs of tourists. The cultural dimension in society is the development of a number of art studios such as dance and percussion which are used to support tourism. The political dimension, in the form of the involvement of all rural tourism communities, in decision making or design, implementation of activities and supervision in the field of tourism.

In providing this facility, the government cooperates with various parties, both private and public. Even under certain conditions the government can act as a dynamic (Pitana and Gayatri, 2005), namely as a party that serves to provide encouragement to the community by creating a conducive development environment.

The results of research and data analysis show that the role of government has a positive and significant effect on the quality of destinations. This means that if the role of the government is improved, the quality of the destinations in the tourist villages will also increase. This fact is an empirical justification regarding the perception of local people who assume that the government has been able to play its role as a motivator, facilitator, and dynamic in the development activities of tourism destinations in Badung Regency. This finding is in line with research conducted by Budiasa, et al., (2014) where the role of government has a positive and significant effect on CBT-based tourism destinations in Buleleng Regency. Steps or programs carried out by the Badung Regency government for the arrangement of tourism village facilities and infrastructure, namely by providing tourism support facilities, conducting monitoring and coaching to the community by empowering, and in collaboration with the community, private sector and related parties in order to develop tourist village.

Even though the role of the government as a motivator, facilitator or dynamic is quite good, the assistance process carried out by village officials has not been maximized. The assistance process must involve local people who understand the problems faced in the tourism village both from the initial stages of planning to evaluation. The results of the search for opinions from informants through in-depth interviews about the role of the government in improving the quality of destinations in the Tourism Village of Badung Regency, as previously revealed, provides justification for the significance of the effect of the government's role on improving the quality of the destination. Government involvement in tourism development activities is a necessity (Markandya, et al., 2003). The role of the government can affect the satisfaction of local people about the existence of tourism in their region, which is a representation of the quality of tourist destinations in an area.

The results of research and data analysis show that community participation directly has a positive and significant effect on the quality of destinations in the Tourism Village of Badung Regency, Bali Province. This means that by increasing public participation the quality of the destination in the tourist village will also increase. The results of this study are justifications of the opinion of Tosun (2002) which says that community participation is one of the vital elements in the formulation of tourism development strategies and actions in a region. Tourism in the tourism village of Badung Regency takes place in the midst of community life that has a different socioeconomic and cultural background than tourists. The rejection and acceptance of the local community on these conditions will be greatly influenced by various motives that are significantly on the level of participation in the development activities.

Community participation in the tourism village of Badung Regency, although considered good by respondents, community participation is still passive. The lack of community involvement in the tourism village of Badung Regency is closely related to work 
opportunities and their ability to manage tourism villages in Badung Regency. The tourism village communities in Badung Regency mostly earn a fortune in big cities like Denpasar, Kuta and Nusa Dua. They work in the city in search of a better life. But if they can get involved in it without realizing they have already participated in introducing and promoting their village. Not much capital is needed to work in one's own area, it requires mental and physical readiness of the community to welcome tourists. During this time the people in the tourism village of Badung Regency just follow the launching of the program, and are waiting to be mobilized. When there will be an event or work program from the provincial and central government, then the Pokdarwis will be directed by the Badung Regency government for its preparation and implementation.

Although there seems to be participation, however, the participation that occurs is pseudo participation. It was said that the participation was pseudo because the community (respondents) participated in the management stage only in the form of utilizing business opportunities, job opportunities, and opportunities to get education and training as well as involvement in maintaining the security and comfort of the tourist village. Whereas community participation recorded high, is at the stage of development management, which according to Arnstein, Sanof, and Pateman, this stage cannot yet be classified as participation.

The results of Leksakundilok's research (2004) found that community experience related to tourism activities in the region will have an influence on the motives for participation. Community initiatives to participate can originate from internal and external factors of local communities. Community experience is one form of determinants of local community participation. Tourism activities that are not accompanied by the control of local communities have the potential to cause a negative impact on culture to look for forms of participation that are broader than just simply obtaining economic benefits. The results of this study are in line with research conducted by Sebele (2010) in Botswana, Africa which states that through involving local people in tourism development activities, the local community will be more empowered and the benefits felt in economic, socio-cultural and environmental conservation aspects will increase which causes hope to realize sustainable tourism even greater.

Claiborne (2010) conducted a study of the effect of participation on tourism development in Bocas del Toro, Panama found that indigenous people of the region, although aware that development has a meaning of progress and greater opportunities for progress for all members of the community stated that tourism development in the region It should be done with full consideration of the opinions of local people, given that uncontrolled tourism development rather than profit can actually harm their social, cultural and environmental arrangements.

The results of research and data analysis show that social capital that has indicators of trust, networks and norms has a positive and significant effect on the quality of destinations in the Tourism Village of Badung Regency. This means that by increasing social capital in the community, the quality of the destination in the tourist village will increase. The dominant social capital is reflected by norm indicators, their presence can be expressed as a driver of destination quality improvement in the Tourism Village of Badung Regency, while the trust indicator has the lowest value of the respondents' perceptions. Community norm is a community perspective which is accepted as a documented form, an unwritten rule or certain behavior which is accepted as a norm in a particular community. This norm will determine the potential for togetherness in forming a strong foundation of social capital so that it can be a supporting parameter for the development of community-based and sustainable tourism.

Social capital owned by the people of Badung Regency such as community harmony in developing tourist villages can be seen from the enthusiasm of the community in participating in the activities held. Mutual cooperation, cleaning the village, helping each other and reminding each other in establishing communication will strengthen the social networks that exist in a tourist village because all levels of society can participate.

In an agrarian community in North Badung the dynamics of norm changes tend to be stagnant and do not easily accept norm changes. On the one hand, the norms of social 
organizations can be unique, so that they are attractive and provide added value to sell as a tourist destination. The sense of togetherness and the spirit of community cooperation is a foundation that will support sustainable community-based tourism. The results of this study found that the norm as one of the components of social capital as a force in the development of community-based tourism destinations (Hamzah and Khalifah, 2009).

The results showed that the role of government had a positive and significant effect on people's welfare. This means that the role of government in its role as a motivator, facilitator and dynamist is able to improve the welfare of the community in the Tourism Village of Badung Regency. The Badung Regency Government has supported the implementation and financing of all development activities, both public facilities and Village Kahyangan and their ceremonies such as piodalan and other ceremonies, so that the people here are helped.

There are various studies on the role of government in the development process in an area (Morgan, 2009). The role of the government to stimulate regional development is more emphasized to the aspects of regulation, investment in infrastructure, marketing and tax incentives that are directed to foster investment climate in the region.

The results of the analysis of research data indicate that community participation has a positive and significant effect on people's welfare. It means that the people of Badung Regency are participating in the development of the tourism village starting from the beginning of the planning, implementation and monitoring, it will improve the realization of better public welfare. Local community participation is an important component of sustainable development in general to meet the needs of present and future generations even though protecting natural resources. The term community participation here is the ability of communities to influence the results of development projects such as tourism development that has an impact on them (Purnamasari, 2011). In the application of a tourism village it is necessary to involve the local community because it is related to the quality and socioeconomic conditions of the local community. Therefore, in order to create sustainable natural resources, the development of tourism villages requires the participation of local communities.

Community participation in the Regency of Badung can be concluded as the willingness of respondents who as a whole participated or participated in the implementation of the development of the tourism area. Communities in the Tourism Village of Badung Regency say that the sustainability of tourism can create jobs and increase income for families. Besides accessing health is easier, more focused on children's education and can have savings for tomorrow. Increasing participation of local communities, in turn, will significantly increase all dimensions of sustainable development. The economic, cultural, and social dimensions of local communities have a positive impact on community participation in tourism development (Untong, Kaosa-ard, Ramos, Sangkakorn, \& Rey-Maquieria, 2010; Sebele, 2010; Claiborne, 2010).

The results of the research and data analysis show that social capital which has indicators of trust, networks and norms has a positive and significant effect on the welfare of the community in the Tourism Village of Badung Regency. The results of this research are in line with the study of researchers Noya \& Clarence (2009), and Kimmo (2010), stating the formation of social capital is a process related to the support of traditions, community norms and the spirit of togetherness traditions that run in line with the dynamics of the community towards the realization of prosperity that is managed together.

The Balinese who are members of an adat village (pakraman) have a social capital in the form of a welfare system (Meniarta, et al., 2009). The forms of social capital for the Indigenous Village community in Bali consist of values, institutions, and mechanisms. The value adopted by the people in Bali is that all citizens are brothers (in unison). In addition, happiness and sadness are felt together (ups and downs). This value makes the impetus for villagers to participate in the order, work together, give each other (ngejot) and social gathering, which is carried out to redistribute welfare to all indigenous villagers (manners) in a fair manner. Likewise with social capital in the tourist village of Badung Regency.

Social capital enables community groups to achieve something (Coleman, 1988; Putnam, 1995). Putnam (1995) also states that social capital encourages people in a 
community to want to engage in collective activities assuming that other members of their community will also do the same. Social capital encourages coordination and cooperation (Putnam, 1995; Pretty \& Ward, 2001). The existence of social capital causes community members will not do things that are detrimental, because other people will not do that (Pretty \& Ward, 2001).

The results showed that the quality of the destination affects the welfare of the community. The existence of a tourism village in Badung regency with unique potential, then the increase in the quality of the destination will lead to increased welfare of the community. Most respondents have felt an increase in welfare received from the existence of a tourist village. The results of this study are in line with the same results obtained by Leksakundilok, (2004) and Aref (2011) who say that tourism provides benefits in increasing local people's income and employment opportunities. The dominant benefit felt is increased employment opportunities and business opportunities for the community.

Opportunities that can be utilized by the local community in the Tourism Village of Badung Regency are as object manager, accommodation manager, souvenir trader, restaurant manager, photographer, parking guard, janitor, percussion artist, dance artist and so on. Tourism activities in an area cause the economic activity of local people to grow. Although in terms of meeting the needs of clothing, food and housing as well as education has not been able to have a major impact on the community in the Tourism Village of Badung Regency.

The existence of a tourism village has a positive impact on society by increasing economic income. The quality of a positive and significant destination for the welfare of the dominant community is reflected by the attraction indicator. This means that the tourism village in Badung Regency has natural, cultural and artificial tourism potential which is very feasible for the development of tourism where this attraction can be a unique tourist attraction that can be sold to bring tourists to the welfare of the community. So that the quality of destinations in the tourist village can benefit the welfare of the community, it is necessary to have good partnership collaboration between the government, community and the private sector.

The results showed that community participation was able to mediate the influence of the government's role on destination quality. This means that increasing community participation in tourism villages will strengthen the influence of the government's role on destination quality. The role of the government by increasing community participation to improve the quality of destinations in the Tourism village of Badung Regency is reflected in three types of roles, namely motivators, facilitators and dynamists. The empowerment carried out by the Badung Regency government is one of the supporting factors in the development of a tourist village. The development of tourism villages is inseparable from the involvement and empowerment of local communities (Prasiasa, 2010).

The results of this study are in line with research conducted by Cameron, et al. (2001) on the West Coast, New Zealand proved that the role of local government was observed through three perspectives, namely: (a) regional economic development initiatives; (b) provision of tourism infrastructure; (c) managing tourism events is able to increase regional economic growth which is reflected through increased income of local residents and increased employment opportunities and business opportunities in the tourism sector. This has led to an increase in the understanding of the local population regarding the importance of tourism in the region which subsequently encouraged the participation of local communities in the development.

Communities in the Tourism Village of Badung Regency view the economic impact of tourism development is the most predictive. This finding is in line with the same results obtained (Leksakundilok, 2004; Aref, 2011) which noted that tourism provides benefits in increasing local people's income and employment opportunities.

The results showed that community participation was able to mediate the influence of the role of government on community welfare through means that increasing community participation in tourism villages would strengthen the influence of the role of government on people's welfare. Increasing participation of local communities, in turn, will significantly 
increase all dimensions of sustainable development. The economic, cultural, and social dimensions of local communities have a positive impact on community participation in tourism development as noted by many researchers (Untong, Kaosa-ard, Ramos, Sangkakorn, \& Rey-Maquieria, 2010; Sebele, 2010; Claiborne, 2010).

The role of the government in the process of regional development must be pursued in such a way that the interests of the local community are the priority of development goals. Accommodating the interests of local communities in development including tourism development will have an impact on increasing community participation. This was confirmed in research conducted by Mayer and Keyes (2005) who examined the role of city government in housing development in three cities in the United States namely Boston, Cleveland and Portland. Mayer and Keyes concluded that housing construction in the three cities was fully supported by the community in each city, paying attention to houses built in accordance with the social and cultural conditions of the community.

The results showed that the quality of the destination was able to mediate the influence of the role of government on people's welfare. The role of the government in the development of tourism villages in Badung Regency, especially in its role as motivators, facilitators and dynamists can encourage the community to play an active role in the development of tourist villages in Badung Regency. The Badung Regency Government has developed infrastructure to support the sustainability of tourism where access to tourist attractions has become easier. The community is also given training on tourism awareness through Pokdarwis in the local village so that they are able to compete with workers from outside the area. The government also supports tourism activities in the village. The government helps the development of rural tourism through village funds to accelerate village development. With the support of the government it is believed that it will continue so that people feel helped and have awareness about the responsibility to develop tourism potential in the village by preserving the environment and preserving culture as a selling power so that tourism development can be felt by the community which will have an impact on the wellbeing of the income side, basic needs, education and health.

The results of this study are in line with research conducted by Cameron, et al (2001) which proves that the role of local government is observed through three perspectives, namely (a) regional development initiatives; (b) provision of tourism infrastructure; and (c) managing tourism events able to increase regional economic growth which is reflected through increased income of local residents and increased employment and business opportunities in the tourism sector. This has led to an increase in the understanding of the local population regarding the importance of tourism in the region which subsequently encouraged the participation of local communities in the development.

The results showed that the quality of the destination is able to mediate the effect of community participation on the welfare of the community. It means that with a good destination quality in the tourism village will strengthen the influence of community participation on the welfare of the community. This is because: (1) community participation has a significant effect on the quality of the destination and (2) the quality of the destination has a significant effect on the welfare of the community. The results of this study are in line with the study of Marhanani (2014) where community participation will arise due to the direct benefits of the environment around tourism. In order to provide benefits, the environment must be maintained. This is a reciprocal relationship between tourism activities, management and benefits derived from the environment around tourism. If nature is preserved, then the people themselves will enjoy it. Likewise with tourism activities, if the preservation of the environment around the tourism area is well maintained, then the people who will benefit economically.

The active role of the community is needed to support the development of the tourism sector in the region. The study of tourist destinations is determined by the presence of community participation as an inseparable part of the development of tourist destinations (Tosun, 2006). The community is a determining component in the development of tourist areas (Aref et al, 2010). The role of the community can determine the success of tourism 
development, where community involvement will lead to support for tourism by the community so that tourism will continue to develop (Ma'rifatul Kholifah, 2015).

As explained by Demartoto (2009) that the local community is the main actor in the development of tourism villages. Research on community participation in the development of tourism villages in Indonesia, shows that the community has a very broad opportunity to participate in every stage of development, where all the knowledge and local wisdom of local communities will be an important input in tourism planning and management; local communities will be able to increase the use of assets and resources for economic activities, cultural conservation and rural environments will be better maintained (Darma P. \& Pitana, I G, 2010; Permanasari, 2011).

The results of research and data analysis show that destination quality is able to mediate the influence of social capital on people's welfare. By mobilizing the potential of social capital in the Badung tourism village as a basis for togetherness including community norms and culture, the potential of community networks in the Badung Regency Tourism Village, as well as arousing public trust to formulate their interests through kinship and togetherness patterns will improve the quality of the destination tourism in the tourist village so that with the increase in the quality of the destination it will have an impact on people's welfare. The results of this research are in line with the study of researchers Noya \& Clarence (2009), and Kimmo (2010), stating the formation of social capital is a process related to the support of traditions, community norms and the spirit of togetherness traditions that run in line with the dynamics of the community towards the realization of prosperity that is managed together.

Cavaye (2008) and Kimmo (2010) report that there is positive support that increasing the source of welfare from the management of local population-based tourist destinations actually strengthens the traditions and culture of the community as a result of the interaction of the lifestyle of tourists with local residents as affected by the intensive interaction of tourists as users services with local residents as tour service providers. Successful tourism development in an area requires a balance between environmental, economic and sociocultural aspects so that a sustainable tourism takes place (Goeldner, Ritchie, and Mclntosh, 2000; Milic, Jovanovic, and Krstic, 2008). The Quebec Declaration lists people as one of the social components that have the role and responsibility to determine the success of natural tourism development through the development of social capital (Word Ecotourism Summit, 2002).

The results of research and data analysis show that community participation and destination quality are able to mediate the influence of the role of government on people's welfare. The results of the search for the opinions of informants about the role of government in community welfare mediated by community participation and the quality of destinations in the tourism village of Badung Regency, as previously revealed, provides justification that in realizing community welfare in the Tourism Village, synergy between the role of government and community participation in realizing tourism-based tourism is needed. community and sustainable. In managing tourism in the tourism village of Badung Regency, the implementation of tourism activities is carried out by the manager by involving the local community. The people in the tourism village are fully aware that the development of tourism should not change the tradition and environmental sustainability in the tourism village of Badung Regency.

The role of the government in improving the welfare of the community in the tourism village will not be in vain if the community is involved in it, in order to improve the quality of existing destinations. So that with the increasing quality of destinations in the tourist village, it will increase tourist satisfaction which will increase the number of tourist visits to the tourist village. This is consistent with the explanation of Yemen and Mohd (2004) that the key to regulating tourism development with a community based tourism (CBT) approach is that there is government support, CBT requires the support of a multi-institutional structure in order to be successful and sustainable. The CBT approach is human oriented which supports fair benefit sharing and supports poverty alleviation by encouraging the government 
and the community to maintain natural and cultural resources, the government will function as a facilitator, coordinator or HR advisory body and institutional strengthening.

\section{RESEARCH LIMITATIONS}

The limitations that can be identified related to this research, namely in the management of tourism destinations, collaboration between the government, the public and the private sector is needed as a partnership model, but in this study only focuses on discussing the role of government and society and social capital in the development of tourism in the Tourism Village of Badung Regency. This study only focused on three research sites, namely Sangeh tourism village, Pangsan tourism village and Belok Sidan tourism village. To get the perception of the community in the tourism village of Badung Regency as a whole it is better to involve all the tourism villages in Badung Regency.

\section{CONCLUSION AND SUGGESTIONS}

Based on the results of the research and discussion described previously, the conclusion of this study is the role of the government directly and positively and significantly influential on community participation in the Tourism Village of Badung Regency. That is, the role of government is a dominant stimulus in increasing community participation in the Tourism Village of the Badung Regency of Bali Province, where social capital is more dominant affect the quality of the destination. That is, social capital becomes the dominant stimulus in improving destination quality in the Tourism Village of Badung Regency, Bali Province. Government role, community participation, social capital and destination quality directly have a positive and significant impact on the welfare of the community in Badung Regency Tourism Village, where destination quality is more dominantly affecting public welfare. That is, the quality of the destination is a dominant stimulus in improving the welfare of the community in the Tourism Village of Badung Regency, Bali Province. Community participation is a mediating variable that is able to play a partial mediating effect of the role of the government on destination quality in the Tourism Village of Badung Regency, Bali Province.

Community participation is a mediating variable that is able to play a partial role in mediating the influence of the government's role on community welfare. Community participation and destination quality are mediating variables that can play a partial role in mediating the effect of the government's role on community welfare in the Tourism Village of Badung Regency, Bali Province.

Based on the conclusions of the research results, the suggestion that can be delivered is that the government needs to increase its role by making harmonious cooperation with the community, the private sector and tourism businesses to improve the quality of destinations in the tourism village of Badung Regency. The government needs to organize tourism in the tourism village by creating natural attractions based on the environment and culture of the community, providing supporting facilities that are not yet owned by the tourism village and empowering the community to increase their participation in the development of the tourism village. The community is advised to increasingly safeguard social capital, especially norms owned by the community in the form of togetherness, the spirit of mutual cooperation and their daily behavior in development. It is necessary to strengthen the tourism village network driven by the Tourism Awareness Group (Pokdarwis) in each tourism village by intensively establishing cooperation and promotion with the tourism industry (PHRI, ASITA), Higher Education and regional tourism villages that have been developed. There is a need for institutional strengthening between traditional villages and official villages and Pokdarwis in tourist villages in order to overcome obstacles in the village. 


\section{REFERENCES}

1. Anom, I Putu, Ida Ayu Suryasih, Ida Bagus Suryawan, I Gst Ag. Oka Mahagangga, I Wayan Mertha. 2015. Laporan Final Kajian Pengembangan Desa Wisata Di Kabupaten Badung. Fakultas Pariwisata-Universitas Udayana.

2. Aref \& Ma'rof. 2008. Barriers of Tourism industry Through Community Capacity Building. International Review of Business Research Papers. Vol. 5 No. 4 June 2009. Hal.399-408.

3. Aref, F. 2011. Sense of Community and Participation for Tourism Development. Life Science Journal, 8(1), pp.20-25.

4. 2011. The Effects of Tourism on Quality of Life: A Case Study of Shiraz, Iran. Life Science Journal, 8(2), pp.26-30.

5. Arif, S.S. 1999. Applying Philosophy of Tri Hita Karana in Design and Management of Subak Irrigation System. A Study of Subak as Indigenous Cultural, Social, and Technological System to Estabilsh a Culturally based Integrated Water Resources Management. Vol. III. (ed: S.Susanto), Fa.of Agric. Technology. Gadjah Mada Univ. Yogyakarta.

6. Baiquni, M and Susilawardani. 2002. Pembangunan Yang Tidak Berkelanjutan Refleksi Kritis Pembangunan Indonesia. Transmedia Global Wacana, Yogyakarta.

7. Budhiasa, Sujana, Eka N. Kencana, Trisna Darmayanti. 2016. Local Communities As Agents For Sustainable Tourism: A Structural Model to Study Tourism Development At Northern Bali Province Indonesia. International Journal of Economics, Commerce and Management, Vol. IV, Issue 10, October 2016

8. Cameron, A.M., Memon, A., Simmons, D.G., Fairweather, J.R., 2001. EvolvingRole of Local Goverment in Promoting Sustainable Tourism Development on the West Coast. Lincoln, New Zealand: Tourism Recreation Researchand Education Centre (TTREC) Lincoln University.

9. Cavaye, J. 2002. The Role of Government in Community Capacity Building. Research Report. Rockhampton: Principal Rural Development Office Department of Primary Industries.

10. Chavis, D.M., Lee, K.S., Acosta, J.D. 2008. The Sense of Community (SCI) Revised: The Reliability and Validity of the SCl-2. In The 2nd International Community Psychology Conference. Lisboa, Portugal, 2008.

11. Claiborne, Petra. 2010. Community Participation in Development and The Value of Social Capital: The Case of Bastimentos, Bocas del Toro, Panama, Not Published, School of business, economic and law, Gothernburg, University of Gothernburg.

12. Cohen, D \& Prusak, L. 2001. In Good Company: How Social Capital Makes Organization Work. London: Harvard Busines press.

13. Coleman, J.S. 1998. Social Capital in the Creation of Human Capital: American Journal of Sociologi, 94, Supplement. S95-S120.

14. Cooper, C. F \& Gilbert, D. W. 1993. Tourism. Principle \& Practice. England. Addison Wesley Longman Group Limited.

15. Darma P., \& Pitana, I G. 2010. Pariwisata Pro-Rakyat: Meretas Jalan Mengentaskan Kemiskinan di Indonesia. Jakarta: Kementrian Kebudayaan and Pariwisata.

16. European Communities.2003. A Manual for Evaluating the Quality Performance of Tourist Destinations and Services. Enterprise DG Publication, Luxembourg.

17. Kimmo, O. 2010. Local Government Association Capasity Building-Rationale, Cooperation Practice, and Strategies for the Future, Local and Regional Gov. Finland.

18. Leksakundilok, A. 2004. 1864872225 Ecotourism and Community-based Ecotourism in The Mekong Region. Working Paper \# 10. Sidney: University of Sidney.

19. Hamzah, A., Khalifah, Z. 2009. Handbook on Community Based Tourism: How to Developm and Sustan CBT. In A Church \& T. Coles (Eds.), Tourism, power and space. Abingdon: Routledge.

20. Hasbullah, Jousairi. 2006. Social Capital (Menuju Keunggulan Budaya Manusia Indonesia), Jakarta: MR United Press. 
21. Markandya, A., Taylor, T. \& Pedroso, S. 2003. Tourism and Sustainable Development: Lessons from Recent World Bank Experience. Research Report. Washington, D.C.: The World Bank IBRD.

22. Meniarta, I Ketut., Mas'udi, Wawan., Dwipayana, A.A.G.N. Ari. 2009. Dinamika Sistem Kesejahteraan and Modal Sosial di Masyarakat Banjar Pakraman-Bali. Jurnal Ilmu Sosial and IImu Politik Volume: 13, Nomor 2, November 2009. pp. 231-248.

23. Mill, R.C., Morrison, A.M. 2012. The Tourism System. United States Of Amerika: Kendall Hunt Publishing Company.

24. Morgan, J. Q. 2009. The Role of Local Government in Economic Development: Survey Findings from North Carolina. Research. Chapel Hill: School of Government University of North Caroline.

25. Nalayani, N.M.H.A. 2014. Evaluasi and Strategi Pengembangan Desa Wisata di Kabupaten Badung. (tesis). Denpasar. Program Pascasarjana Universitas Udayana.

26. Natori, Masahiko. 2001. A Guide Book for Tourism-Based Community Development. Yokohama: Asia Pasific Tourism Exchange Center.

27. Permanasari, I K. 2011. Pemberdayaan Masyarakat melalui Desa Wisata dalam Usaha Peningkatan Kesejahteraan. Thesis, Magister Perencanaan and Kebijakan Publik. Pascasarjana, FE, Universitas Indonesia, Jakarta. Tidak diterbitkan.

28. Pitana, I G., 1999. Pelangi Pariwisata Bali. Kajian Aspek Sosial Budaya Kepariwisataan Bali di Penghujung Abad, BP, Denpasar.

29. 2002. "Daya Dukung Bali terhadap Kepariwisataan and Sosial Budaya". Dalam: I Gusti Ngurah Bagus, editor. Pembangunan Bali Berwawasan Budaya. Edisi Khusus. Denpasar: Majalah IImiah Pusat Penelitian Universitas Udayana. Tahun I No.1. hal 62-70

30. Pitana, I G., and Gayatri. 2005. Sosiologi Pariwisata. Yogyakarta: Penerbit Andi.

31. Prasiasa, D.P.O. 2010. "Pengembangan Pariwisata and Keterlibatan Masyarakat di Desa Wisata Jatiluwih Kabupaten Tabanan". (disertasi). Denpasar: Program Pascasarjana Universitas Udayana.

32. Pretty, Jules N.1995 .Participatory Learning and Action; A Trainer's Guide. 267pp, ISBN:189825002, HED.

33. Putnam, R.D., 1995. Bowling Alone: America's Declining Social Capital. Journal of Democracy, 6(1), pp.65-78.

34. Richardson, John I and Martin Fluker. 2004. Understanding and Managing Tourism Australia. NSW: Pearson Education.

35. Scheyvens, R. 2002. Tourism for development: empowering communities. Harlow: Prentice Hall.

36. Sebele, L. S. 2010. Community-based tourism ventures, benefit and challenges: Khama Rhino Sanctuary Trust, Central District, Botswana. Tourism Management, 31, p.136=146.

37. Sharpley, R. 2002. Tourism and Development: Concepts and Issues. Multilingual Matters Limited.

38. 2009. Tourism Development and the Environment: Beyond Sustainability? New York: Earthscan.

39. Timothy, D.J. 1999. Participatory Planning: a View of tourism in Indonesia. Annals of Tourism Research, 26, pp.371-91.

40. Tosun, C. 1999. Towards a Typology of Community Participation in the Tourism Development Process. Anatolia: An International Journal of Tourism and Hospitality Research, 10(2), pp.113-34.

41. 2002. Host Perception of Impact: A Comparative Tourism Study. Annals of Tourism, 29 (1), pp. 231-53

42. 2006. Expected nature of community participation in tourism development. Tourism Management, 27(3), pp.493-504.

43. Yaman, A.R. \& Mohd, A., 2004. Community-based Ecotourism: A New Proposition for Sustainable Development and Environmental Conservation in Malaysia. Journal of Applied Science, 4(4), pp.583-89.

44. Zhao, W. \& Ritchie, J.R.B., 2007. Tourism and Poverty Alleviation: An Integrative Research Framework. Current Issues in Tourism, 10, pp.119-43. 